\title{
The Reality of Employing Student-Centred Learning Strategies in Psychology Course from the Teachers' Perspective in Kuwait
}

\author{
Abed Al-Rahman Shamekh Ayed Snaitan Al-Ershaidy
}

\begin{abstract}
The present study aimed to explore the reality of employing student-centred learning strategies in psychology course from the teachers' perspective in Kuwait. Those strategies are represented in the problem-based and projectbased strategies. The researcher selected a purposive sample that consists from 40 female and male teachers who teach psychology course. Those teachers were selected from 40 schools located in Al-Farwaniyah, Kuwait. Questionnaire forms were distributed to those teachers. All the forms were retrieved and deemed valid for analysis. SPSS software was employed for having the data analysed. It was found that the extent of employing the studentcentred learning strategies (i.e. problem-based and project-based strategies) in psychology course from the teachers' perspective in Kuwait in high. The researcher recommends conducting studies about the effectiveness of employing student-centred learning strategies in other courses in Kuwiat.
\end{abstract}

Keywords: Student-centred strategies, psychology, Kuwait, teachers, reality.

DOI: $10.7176 /$ RHSS/10-22-01

Publication date: November $30^{\text {th }} 2020$

\section{Introduction}

Much attention has been given to the teaching and learning strategies employed in psychology courses. There are many strategies employed in such courses. Such strategies include: the student-centred strategies. The studentcentred strategies refer to the strategies in which students shall be constructing knowledge by themselves instead of having a teacher transmitting knowledge directly to them. They involve learning by doing (i.e. the student shall learn through applying the things he/she has learnt). Through such strategies, the teacher shall serve as a facilitator of knowledge. The effectiveness of such strategies are affected by the students' engagement and motivation levels. It is affected by the teachers' performance as a guide (Krishnan, 2015).

Through employing the student-centred strategies, the teacher shall provide students with opportunities to learn independently or in peers. The latter strategies shall improve the students' retention, because students shall see the application of knowledge in front of them. They enable students to meet the changing demands of life by themselves. That is because such strategies develop students' capability to learn by themselves and depend on themselves (Ahmad, 2016).

Employing the student-centred strategies requires from students to use their critical and creative thinking skills. It requires from students to employ their communication and inquiry skills. Thus, it shall contribute to developing such skills (Ahmad, 2016). In addition, the student-centred strategies shall promote autonomy among students, because students shall become responsible for managing their own learning process by themselves. They shall turn students into active learners. That is because those strategies shall make students involved in the learning activities. The student-centred strategies contribute to promoting a better interaction among students, because students shall probably work together to reach the desired knowledge. They contribute to promoting deep learning. (Krishnan, 2015). It should be noted that there are various students centred teaching strategies, such as: groupbased learning strategy (Krishnan, 2015), the problem-based learning strategy (Ali, 2019), the project-based learning strategy (Kokotsaki et al., 2016) and etc..

The problem-based learning strategy is represented in presenting a problem before students in order for them to learn through addressing it and suggesting solutions. It's often employed in groups. It requires understanding and analysing the problem. Thus, it improves students' analysis skills. Employing this strategy requires searching for information and acquiring knowledge. Thus, it contributes to developing students' knowledge acquisition skills because students have to acquire knowledge by relying on themselves. It improves students' self-assessment skills, because it lets students assess their own learning outcomes by themselves. It contributes to promoting creativity because it requires coming up with creative ideas and solutions (Benjamin and Keenan, 2015)

The problem-based learning strategy improves students' problem-solving skills, through receiving opportunities to solve various types of problems in order to learn. It promotes enthusiasm among students, because students shall feel challenged to solve the concerned problem (Abdelkarim et al., 2018). It makes learning a meaningful process, because it enables students to connect their previous information with the new one. It motivates students to acquire more information and learn, because students shall enjoy the experience of controlling their own learning process by themselves. It is because students shall feel challenged to solve the (Arman, 2018).

The problem-based learning strategy plays an important role in in developing the skills that are required for cooperation. It promotes cooperation among students while they are working together and learning. It enables 
students to gain more factual knowledge and promote a deeper understanding for the knowledge that was gained. That is because seeing the way of utilizing information for solving a specific problem shall enhance one's understating for information (Arman, 2018).

Another student-centred learning strategy is the project-based learning strategy. The project-based learning strategy is a learning strategy that involves working on a project in peers, with a group or individually. It improves students' collaboration, and communication skills. That is because when working on a group project, students shall interact with each other and exchange opinions. The project-based learning strategy improves students' goalsetting skills, because working on a project requires determining the primary and secondary goals that must be met (Kokotsaki et al., 2016; Blumenfeld et al., 1991).

Employing the project-based learning strategy leads to turning the students into active learners. It improves the teachers' efficiency in managing the classroom. It makes the learning process an enjoyable process because students enjoy implementing information to real life situations. It contributes to developing students' thinking skills because it encourages them to ask questions, hold discussions, and express their opinions (Rofieq et al., 2019).

The project based strategy contributes to the development of the students' 21 century skills. It prepares students to become productive citizens. That is because students shall learn the way of utilizing knowledge to become productive. The project based strategy contributes to preparing students to have a successful career in the future. That is because this strategy develops several skills that are needed in real life situations and workplace. The project based strategy improves students' academic achievement on tests. That is because working on a project shall improve students understanding for information (Williams, 2017)

The project based strategy contributes to expanding students' knowledge and inquiry skills. That is because working on a project requires searching for information and consulting teachers, professionals and experts. It is because working on a project shall let students share their knowledge with each other (Williams, 2017). In the light of the aforementioned information, the researcher believes that it is necessary to conduct studies about the reality of employing the student-centred learning strategies in various courses. Thus, he aimed to explore the reality of employing the student-centred learning strategies in psychology course from the teachers' perspective in Kuwait. The targeted strategies are: the problem-based and project-based learning strategies.

\section{The Study's Objective}

The present study aimed to explore the reality of employing the student-centred learning strategies in psychology course from the teachers' perspective in Kuwait. The targeted strategies are: the problem-based and project-based strategies.

\section{The Study's Question}

This study aimed to answer this question:

What's the reality of employing the student-centred learning strategies -specifically the problem-based and project-based learning strategies- in psychology course from the teachers' perspective in Kuwait?

\section{Significance of the Study}

This study is significant due because:

-This is the first study that aims at investigating the reality of employing student-centred learning strategies in psychology course from the teachers' perspective in Kuwait. That means that this study fills a gap in the research related to teaching psychology course.

-This study provides officials in the Kuwaiti Ministry of education with information about the instructional strategies employed by teachers for teaching psychology. Thus, it contributes to improving the quality of school education in Kuwait.

-This study promotes awareness among the teachers teaching psychology about the significance of employing the problem-based and project-based strategies.

\section{The Study's Limits}

This study was conducted during the first semester of the academic year (2019/2020). It was conducted in 40 schools in Al-Farwaniyah, Kuwait. It targets the school teachers who teach psychology in Kuwait.

\section{Definition of Terms}

-The student-centred strategies: They refer to the strategies that let the students construct knowledge by themselves instead of having a teacher transmitting knowledge to them directly. They involve learning by doing. In other words, they let the students learn through applying the things they have learnt. Through employing such strategies, the teacher shall serve as a facilitator in the process of acquiring knowledge. The effectiveness of such strategies are affected by the students' engagement and motivation levels and the teachers' performance as a guide (Krishnan, 
2015).

-The problem-based learning strategy: It is represented in presenting a problem before students in order for them to learn through addressing it and suggesting solutions. It is often employed in groups. It requires understanding and analysing the problem. Thus, it improves students' analysis skills (Benjamin and Keenan, 2015).

-The project based learning strategy: It is a learning strategy that can be employed by any learner regardless of his/her age. It can be employed individually or in groups or in peers. It involves working on a project and conducting an in-depth investigation in the aim of reaching knowledge (Blumenfeld et al., 1991).

\section{Theoretical framework}

\subsection{The methodology of Employing the Problem-based Strategy}

When employing the problem-based strategy, the teachers must come up with a problem and illustrate it for students. The problem must be complex in order for students to feel motivated to address it and ask questions about it. It must be consistent with the content of the course and the lesson. The teacher can divide the students into groups based on their skills when employing this strategy in order for students to come up with different solutions. The teacher should ask students to carry out critical analysis when addressing a problem. Otherwise, students will fail in addressing problems. That is because the critical analysis enables the students to pay attention to all the aspects and details of the problem (Ali, 2019).

According to Ali (2016), when employing the problem-based strategy, there is a specific methodology that must be applied. This methodology is represented in the following steps: 1)-Analysing the relevant scenario associated with the problem: Such an analysis shall enable students to understand the problem and the associated conditions and circumstances 2)- Developing hypotheses: That shall enable students to assume the potential reasons behind the problem. 3)- Listing down the known information: This step involves writing down the known facts and information about the problem: It shall enable students to eliminate any unreliable information. 4) Listing the unknown: It shall enable students to know what information to search for. It shall enable students to know which questions should be asked while addressing the problem. 5)- Listing what needs to be done: It shall enable students to be systematic in the process of addressing the problem. 6)- Gathering information: It shall enable students to adopt scientific methods in addressing the problem. 7)-Presenting findings before the teachers and their colleagues 8)- Holding discussions: Discussions should be held to assess how effective the proposed solutions are (Ali, 2019).

The problem-based strategy can be employed in class through illustrating the methodology to be used for addressing problems. This methodology involves the following those steps: 1)-understanding the problem, 2)developing a plan for addressing the problem, 3)- addressing the problem, and 4)- assessing the effectiveness of the solution (or measure) used for addressing the problem. When implementing this methodology, the teacher should ask the students questions when finding them facing difficulty in reaching a solution. Such questions should simplify the process of reaching knowledge (Najem, 2016).

\subsection{The methodology of Employing the Project-based Strategy:}

It should be noted that the project-based strategy can be employed through dividing students in groups or letting them work individually (Kirschner et al., 2008). Al-Yamani and Askar (2010) suggest that there are several types of projects that students can work on in the aim of learning. Such types of projects include: 1)-the productive projects, 2)- the leisure-based projects, 3)-the problem solving-based projects and 4)- the skill acquisition-based projects. Regarding the productive projects, they refer to the projects that let the students produce a specific product (e.g. making soap, or vegetable oils). The leisure-based projects refer the projects that students enjoy doing, such as: (visiting an institution or going on a scientific trip) (Al-Yamani and Askar, 2010).

The problem solving-based projects refer to the projects that let the students solve a specific problem. Such a problem may be social, intellectual, environmental or etc.. For instance, students may be asked to suggest solutions for addressing the bullying problem at school. Regarding the skill acquisition-based projects, they aim at letting the students master a new skill. Such a skill may be scientific, social, or IT. For instance, the skill acquisition-based projects include asking the student to develop a new program or use a specific program for doing homework. They include asking the students to conduct interviews with educational experts to develop their skills in making interviews (Al-Yamani and Askar, 2010). Williams (2017) suggests that working on a project has various patterns. For instance, the teacher may divide the students in groups to conduct research. He/she may divide the students in groups to solve a problem (Williams, 2017)

\section{Empirical Studies}

\subsection{Problem-based strategy}

Al-Khateeb and Ababneh (2011) aimed to explore the effectiveness of employing the problem-based learning strategy in math course in improving the mathematical thinking of seventh grade students in Jordan. They aimed to explore the effectiveness of employing this strategy in improving students' attitudes toward the math course. 
They selected a sample that consists from 104 seventh grade students who were divided into experimental and control groups. Based on the results of the analysis, the problem-based learning strategy improves students' academic achievement in math. It also improves students' attitudes towards the math course. It improves students' mathematical thinking and promote a better understanding for mathematical information.

Awan et al. (2012) aimed to explore the impacts of employing the problem-based learning strategy on school students' academic achievement and critical thinking skills in Pakistan. They aimed to explore the impact of this strategy on school students' attitudes towards the learning process in Pakistan. 79 tenth grade students were sampled from Sargodha, Pakistan. A questionnaire was used. In addition, a pre-test and a post-test were employed. The latter scholars found that the problem-based learning strategy has a positive significant impact on students' academic achievement and critical thinking skills. The latter strategy improves students' attitudes towards the learning process.

Treesirichod et al. (2018) aimed at investigating views of the students majoring in medicine in Thailand towards the problem-based learning strategy during the clinical year. 387 students were sampled by the latter scholars. Those students were majoring in medicine and in their clinical year. They were chosen from the faculty of medicine at Srinakharinwirot University which is located in Thailand. A questionnaire was employed for collecting the required data. Several findings were reached. For instance, the students have positive attitudes towards the problem-based learning strategy. In addition, the latter strategy develops students' communication skills. It develops the skills that are needed for working in a team. It improves the information inquiry skills because students must ask for the information they need to reach knowledge. It improves students' capability to adopt a self-directed learning approach. It develops the critical thinking of students because information must be analysed in a critical manner to solve the problem. It improves students' information retention, and ability to express their views. It enhances students' presentation skills. It develops students' listening and leadership skills. However, employing this strategy is stressful, and time consuming, especially when having too many students in classroom

\subsection{Project-based strategy}

Awad (2017) aimed to explore the effectiveness of employing the project-based learning strategy in earth and environmental science course in raising the eleventh grade female students' academic achievement and visualspatial thinking skills. He selected a purposive sample. The sample was selected from two schools in Jordan. It consists from 59 female eleventh grade students. It is divided into experimental and control groups. The control group consists from 29 students. The experimental group consists from 30 students. The members of the experimental group were taught through employing the project-based learning strategy. Through conducting a statistical analysis, the latter scholars found that the project-based learning strategy improves the eleventh grade female students' academic achievement, understanding and visual-spatial thinking skills.

Apsari et al. (2019) aimed at investigating the views of fourth grade students for project based learning strategy. 41 fourth grade students were sampled. A questionnaire was used for data collection. The researchers concluded that this strategy enhances the students' critical thinking skills. This strategy also promotes creativity among fourth grade students. It enhances the team work skills of fourth grade students and provides them with opportunities to share their ideas with others. It makes students highly interested in learning. It develops students' knowledge acquisition skills.

\section{Methodology:}

9.1. Approach

A descriptive analytical approach is adopted.

\subsection{Sample and Population}

The population is represented in all the teachers who teach psychology in Kuwait. The researcher selected a purposive sample from this population. He selected 40 female and male teachers who teach psychology. Those teachers are selected from 40 schools in Al-Farwaniyah, Kuwait. Questionnaire forms are distributed to those teachers. All the forms were retrieved and deemed valid for analysis. Table (1) presents data about the sample.

Table (1): Data about the sample

\begin{tabular}{|l|l|l|l|}
\hline Variable & Category & Frequency & Percentage \\
\hline \multirow{2}{*}{ Gender } & Male & 20 & 50 \\
\cline { 2 - 4 } & Female & 20 & 50 \\
\hline
\end{tabular}

$\mathrm{N}=40$

\subsection{Instrument}

The researcher used a questionnaire. This questionnaire aims to collect data about the reality of employing studentcentred strategies -specifically the problem-based and the project-based strategies- in teaching psychology from 
the teachers' perspective in Kuwait. It consists from two parts. The first part collects data about the reality of employing the problem-based strategy in teaching psychology. It was developed based on the study conducted by Najem (2016). The second part collects data about the reality of employing the project-based strategy in teaching psychology. It was developed based on the study conducted by Ali (2019).

\subsection{Validity of the Instrument}

The initial version of the questionnaire was passed to 2 instructors. Those instructors were chosen from a university in Jordan. They are specialized in teaching methods. They are asked to assess the questionnaire and its capability to meet the intended goals. They added that the questionnaire provides readers with reliable and accurate results. They added that the language is clear and the intended results shall be met through using the questionnaire. The questionnaire was passed to the respondents and the selected instructors in Arabic language. Then, the researcher passed the questionnaire to a translator to translate it into English language.

\subsection{Reliability of the Instrument}

The Cronbach alpha values are shown below

Table (2): Cronbach alpha values

\begin{tabular}{|l|l|l|}
\hline No. & Area & Cronbach alpha \\
\hline 1. & Items related to the problem-based strategy & 0.81 \\
\hline 2. & Items related to project-based strategy & 0.79 \\
\hline & Total & 0.80 \\
\hline
\end{tabular}

Based on all the values, the questionnaire is very reliable. That's because such values are greater than 0.80 as it's suggested by Salehi \& Farhang (2019).

\subsection{Statistical analysis:}

The SPSS program was employed by the scholar. In addition, standard deviations along with means were calculated. The scholar also calculated frequencies and percentages. The criteria employed for having the means classified are listed below:

Table (3): The criteria that are used by the researcher for classifying means

\begin{tabular}{|l|l|l|}
\hline Range & Level & Attitude \\
\hline 2.33 or less & Low & Negative \\
\hline $2.34-3.66$ & Moderate & Neutral \\
\hline 3.67 or more & High & Positive \\
\hline
\end{tabular}

*Source: Al-Amery (2020)

Regarding the five point Likert scale, it consists from five (5) rating categories that are shown below.

Table (4): The categories and scores of the five point Likert scale

\begin{tabular}{|l|l|l|l|l|l|}
\hline Category & Always & Often & Sometimes & Rarely & Never \\
\hline The score it represents & 5 & 4 & 3 & 2 & 1 \\
\hline
\end{tabular}

\section{Discussion and Results}

10.1. Discussion and Results Related to problem-based strategy

To explore the reality of employing the problem-based strategy learning strategy in psychology course in Kuwait from the teachers' perspective, standard deviations and means are calculated and presented below

Table (5): The reality of employing the problem-based learning strategy in psychology course in Kuwait from the teachers' perspective

\begin{tabular}{|l|l|l|l|l|l|}
\hline No. & Area & Mean & Std. & Level & \\
\hline 1. & I let students work in groups to solve a problem that I mention & 4.68 & 0.51 & High & 2 \\
\hline 2. & $\begin{array}{l}\text { When employing the problem-based strategy, I illustrate the methodology } \\
\text { used for addressing problems in classroom }\end{array}$ & 4.53 & 0.23 & High & 3 \\
\hline 3. & $\begin{array}{l}\text { When employing the problem-based strategy, I ask students to understand } \\
\text { the problem before addressing it }\end{array}$ & 4.72 & 0.11 & High & 1 \\
\hline 4. & $\begin{array}{l}\text { When employing the problem-based strategy, I ask students to develop a } \\
\text { plan for addressing the problem }\end{array}$ & 4.25 & 0.37 & Low & 6 \\
\hline 5. & $\begin{array}{l}\text { When employing the problem-based strategy, I ask students to assess the } \\
\text { effectiveness of each other's solutions when addressing a problem }\end{array}$ & 4.37 & 0.58 & High & 5 \\
\hline 6. & $\begin{array}{l}\text { When employing the problem-based strategy, I ask the students questions } \\
\text { when they face difficulty in addressing a problem }\end{array}$ & 4.40 & 0.27 & High & 4 \\
\hline & Total & 4.49 & 0.34 & High & \\
\hline
\end{tabular}

Based on table (7), the overall mean is 4.49. That means that the extent of employing the problem -based 
learning strategy in psychology course in Kuwait from the teachers' perspective is high. This result indicates that the teachers teaching psychology in Kuwait have much awareness about the significance of employing this strategy when teaching psychology.

Statement (3) states the following (When employing the problem-based strategy, I ask students to understand the problem before addressing it). The mean of this statement is 4.72 which is high. That means that the teachers who teach psychology in Kuwait realize the significance of understanding the problem and analysing it before addressing it. Such understanding shall enable students to provide effective solutions of high quality. It shall enable students to dedicate less time for addressing the problem.

Statement (4) states the following: (When employing the problem-based strategy, I ask students to develop a plan for addressing the problem). The mean of this statement is 4.25 . It is high. This indicates that the teachers who teach psychology in Kuwait have much awareness about the significance of being systematic in the process of addressing problems in classroom. Being systematic in addressing plans shall enable students to be wellorganized. It shall enable students to take all the aspects of the problem into consideration while addressing it.

\subsection{Discussion and Results Related to project-based Strategy}

To explore the reality of employing the project -based learning strategy in psychology course in Kuwait from the teachers' perspective, means are presented below:

Table (6): The reality of employing the project -based learning strategy in psychology course in Kuwait from the teachers' perspective

\begin{tabular}{|l|l|l|l|l|l|}
\hline No. & Area & Mean & Std. & Level & Rank \\
\hline 1. & I let students work on project in peers & 4.05 & 0.43 & High & 5 \\
\hline 2. & I let students work on project individually & 4.77 & 0.28 & High & 1 \\
\hline 3. & I let students work on project in groups & 4.16 & 0.25 & High & 4 \\
\hline 4. & $\begin{array}{l}\text { I ask students to work in groups to gather information about a specific } \\
\text { psychological problem }\end{array}$ & 4.23 & 0.61 & High & 3 \\
\hline 5. & $\begin{array}{l}\text { I ask students to work in groups to make a presentation about a specific } \\
\text { psychological problem }\end{array}$ & 4.38 & 0.29 & High & 2 \\
\hline 6. & total & 4.31 & 0.37 & High & \\
\hline
\end{tabular}

Based on table (6), the overall mean is 4.31 which is high. It indicates that the extent of employing the project -based learning strategy in psychology course in Kuwait from the teachers' perspective is high. This result indicates that the teachers teaching psychology in Kuwait have much awareness about the significance of employing this strategy when teaching psychology.

Statement (2) states the following: (I let students work on project individually). The mean of statement (2) is 4.77. It is high and ranked first. It indicates that teachers provide much attention to the projects that require working in an individual manner. That shall contribute to promoting independency among students. It shall contribute to promoting life-long learning approach among students.

Statement (5) states the following: (I ask students to work in groups to make a presentation about a specific psychological problem). The mean of this statement is 4.38 which is high and ranked second. It indicates that the teachers teaching psychology in Kuwait realize the significance of working in groups to make presentations. Such work shall contribute to developing students' presentation skills.

Statement (1) states the following: (I let students work on project in peers). The mean of statement (1) is 4.05 which is high and ranked last. It indicates that teachers provide much attention to the projects that require working in peers. For instance, such kind of projects shall contribute to promoting interaction among students and improving their social skills.

\section{Conclusion and Recommendations:}

The researcher found that the extent of employing student-centred learning strategies (i.e. problem-based and project-based strategies) in psychology course from the teachers' perspective in Kuwait in high. That means that the teachers who teach psychology in Kuwait are highly aware about the significance of student-centred learning strategies. In the light of the results, the researcher recommends:

-Providing the teachers who teach psychology in Kuwait with more training courses about the way of employing the student-centred learning strategies. That shall develop those teachers professionally

-Providing the teachers who teach psychology in Kuwait with more training courses about the way of using technology for employing the student-centred learning strategies.

-Conducting studies about the effectiveness of employing student-centred learning strategies in other courses in Kuwiat.

- Conducting a study about the reality of employing student-centred learning strategies in psychology course from the students' perspective in Kuwait 


\section{References}

References in English Language:

Abdelkarim, A., Schween, D., \& Ford, T. (2018). Attitudes Towards Problem-Based Learning of Faculty Members at 12 U.S. Medical and Dental Schools: A Comparative Study. Journal of dental education, 82(2), $144-151$. https://doi.org/10.21815/JDE.018.019

Ahmad, A. (2016). Learner-centered Instruction in English Education: Reality and Expectations. Arab World English Journal (AWEJ), 7(1).108-122

Al-Amery, A. (2020). Attitudes of the students at the institutes of fine arts in Iraq towards implementing active learning strategies in Arabic language courses and the associated challenges. Journal of Education and Practice, 11(13), 73-81

Ali, S. (2019). Problem Based Learning: A Student-Centered Approach. English Language Teaching. 12(5), p.7378

Apsari, Y.;. Mulyani, E. \& Lisdawati, I. (2019). Students' attitudes towards implementation of project based learning. Journal of Educational Experts (JEE). 2. 123. 10.30740/jee.v2i2p123-128.

Arman, A. (2018). Students' Attitudes toward problem based learning - Analog electronic course in the electrical engineering programs in PPU: case study. Journal of e-Learning and Higher Education, Vol. 2018. DOI: $10.5171 / 2018.142370$

Awan, R.; Hussain, H.; and Anwar, N. (2017). Effects of Problem Based Learning on Students' Critical Thinking Skills, Attitudes towards Learning and Achievement. Journal of Educational Research. 20(2).

Benjamin, C. and Keenan, C. (2015). Implications of introducing problem-based learning in a traditionally taught course. Engineering Education, 1(1)

Blumenfeld, P., Soloway, E., Marx, R., Krajcik, J., Guzdial, M. \& Palincsar, A. (1991). Motivating project-based learning: sustaining the doing, supporting the learning. Educational Psychologist, 26, 369-398.

Kirschner F., Paas F., Kirschner P.A. (2008) Individual Versus Group Learning as a Function of Task Complexity: An Exploration into the Measurement of Group Cognitive Load. In: Zumbach J., Schwartz N., Seufert T., Kester L. (eds) Beyond Knowledge: The Legacy of Competence. Springer, Dordrecht. https://doi.org/10.1007/978-1-4020-8827-8_4

Krishnan, S. (2015). Student-Centered Learning in a First Year Undergraduate Course. International Journal of Learning, Teaching and Educational Research. 11(2). 88-95

Kokotsaki, D.; Menzies, V.; and Wiggins, A. (2016). Project-based learning: A review of the literature. Improving Schools, 19(3), 267-277. https://doi.org/10.1177/1365480216659733

Rofieq, A., Latifa, R., Susetyarini, E., \& Purwatiningsih, P. (2019). Project-based learning: Improving students' activity and comprehension through lesson study in senior high school. JPBI (Jurnal Pendidikan Biologi Indonesia), 5(1), 41- 50. doi: https://doi.org/10.22219/jpbi.v5i1.7456

Salehi, M., \& Farhang, A. (2019). On the adequacy of the experimental approach to construct validation: the case of advertising literacy. Heliyon, 5(5). Retrieved from: https://doi.org/10.1016/j.heliyon.2019.e01686

Treesirichod, A., Chansakulporn, S., Phivthong-ngam, L., Kusumaphanyo, C., Sangpanich, A. (2018). The attitudes of medical students towards problem-based learning during the clinical years. South-East Asian Journal of Medical Education. 12(1).

Williams, D. (2017). The Impact of Project-Based Learning on Fourth-Grade Students' Understanding in Reading. Published Dissertations. Capella University. Minnesota, The United States https://eric.ed.gov/?id=ED576105

\section{References in Arabic Language:}

Al-Khateeb, M.; and Ababneh, A. (2011). Thinking and Attitudes towards Mathematics with Seventh Graders in Jordan. Dirasat: Educational Sciences, 38(1).

Al-Yamani, A. and Askar, A. (2015). General teaching methods. Dar Zamzam, Amman: Jordan

Awad, A. (2017). The Effect of Teaching Earth And Environmental SciencesBy Using Project Based - Learning Strategy On Achievement of First Secondary Female Students And Their Visual - Spatial Thinking. Published MA thesis. The Middle East University. Jordan

Najem, K. (2016). The impact of using the problem solving method in teaching math on developing the number sense of fifth grade primary school students. The Journal of the Association of Arab Universities for education and psychology, 14(4). 140-163 